\title{
Chryseobacterium xinjiangense sp. nov., isolated from alpine permafrost
}

\author{
Qi Zhao, ${ }^{1}$ Yu Bai, ${ }^{1}$ Gaosen Zhang, ${ }^{2}$ Shan Zhu, ${ }^{1}$ Hongmei Sheng, ${ }^{1}$ \\ Yaxuan Sun $^{2}$ and Lizhe $A n^{1,2}$
}

Correspondence

Lizhe An

lizhean@|zu.edu.cn

\author{
${ }^{1}$ Key Lab of Arid and Grassland Agroecology of MOE, School of Life Sciences, Lanzhou University, \\ Lanzhou 730000, PR China \\ ${ }^{2}$ Key Laboratory of Desert and Desertification, Cold and Arid Regions Environmental and \\ Engineering Research Institute, Chinese Academy of Sciences, Lanzhou 730000, PR China
}

Strain TSBY $67^{\top}$ was isolated during a study on the phylogenetic diversity of culturable bacteria from alpine permafrost in Tianshan Mountains, China. On the basis of $16 \mathrm{~S}$ rRNA gene sequence analysis, strain TSBY $67^{\top}$ was closely related to members of the genus Chryseobacterium and exhibited $96.8 \% 16 \mathrm{~S}$ rRNA gene sequence similarity to Chryseobacterium aquaticum $10-46^{\top}$ and Chryseobacterium soldanellicola PSD $1-4^{\top}$. Strain TSBY $67^{\top}$ grew aerobically, at $4-37{ }^{\circ} \mathrm{C}$, with $0-2 \% \mathrm{NaCl}$ and at $\mathrm{pH} 6-8$. Cells were Gram-staining negative, non-motile and non-spore-forming rods. The dominant cellular fatty acids were iso- $\mathrm{C}_{15: 0}(26.9 \%)$, iso- $\mathrm{C}_{17: 0}$ $3-\mathrm{OH}(16.1 \%)$ and iso- $\mathrm{C}_{17: 1} \omega 9 c(15.4 \%)$. The $\mathrm{G}+\mathrm{C}$ content of the DNA was $33.5 \mathrm{~mol} \%$. Strain TSBY $67^{\top}$ was distinguishable from its closest phylogenetic neighbours by a combination of phenotypic characteristics. Therefore, strain TSBY $67^{\top}$ represents a novel species of the genus Chryseobacterium, for which the name Chryseobacterium xinjiangense sp. nov. is proposed. The type strain is TSBY $67^{\top}$ (=NRRL B $-51308^{\top}=$ CCTCC AB $\left.207183^{\top}\right)$.
The genus Chryseobacterium was defined by Vandamme et al. (1994) on the basis of rRNA cistron similarity studies and phenotypic characteristics. The genus originally comprised six species: Chryseobacterium balustinum, C. indologenes, C. indoltheticum, C. meningosepticum, C. scophthalmum and C. gleum (type species). At the time of writing, the genus Chryseobacterium comprised 47 recognized species (http.//www.bacterio.cict.fr/). On the basis of phenotypic and genotypic characteristics, C. meningosepticum (Vandamme et al., 1994) and Chryseobacterium miricola (Li et al., 2003) were transferred to the genus Elizabethkingia (Kim et al., 2005) and species of the genera Sejongia and Kaistella were transferred to the genus Chryseobacterium (Kämpfer et al., 2009a, b). Members of the genus Chryseobacterium are distributed in a variety of environments, such as soil, fresh water, marine habitats, plants, food products (including raw cow's milk, fish, poultry and lactic acid beverages) and human clinical samples (Shimomura et al., 2005; Park et al., 2006; Vaneechoutte et al., 2007; Hantsis-Zacharov \& Halpern, 2007; Hantsis-Zacharov et al., 2008; Ilardi et al., 2009). During a previous study (Bai et al., 2006), strain TSBY $67^{\mathrm{T}}$ was isolated from a sample of alpine permafrost that was collected at the mouth of an ice-free cirque in the

The GenBank/EMBL/DDBJ accession number for the $16 \mathrm{~S}$ rRNA gene sequence of strain TSBY $67^{\top}$ is DQ166169.

A supplementary figure is available with the online version of this paper.
Tianshan Mountains, China (43 $07^{\prime} 10.2^{\prime \prime} \mathrm{N} 86^{\circ} 49^{\prime} 28.2^{\prime \prime} \mathrm{E}$; altitude $3833 \mathrm{~m})$.

For phenotypic tests and fatty acid analysis, the reference strains Chryseobacterium aquaticum $10-46^{\mathrm{T}}$, C. soldanellicola PSD $1-4^{\mathrm{T}}$ and $C$. soli KACC $12502^{\mathrm{T}}$ were grown under the same conditions as strain TSBY $67^{\mathrm{T}}$. Cell morphology was examined by TEM (JEM 1230; JEOL) using cells grown for 3 days at $20{ }^{\circ} \mathrm{C}$ on peptone-yeast extract-glucose (PYG) medium and negatively stained with $1 \%$ phosphotungstic acid ( $\mathrm{pH}$ 7.0). The Gram reaction was carried out as described by Gerhardt et al. (1994). Flexirubin-type pigments were detected with $20 \%(\mathrm{w} / \mathrm{v}) \mathrm{KOH}$ according to the method of Bernardet et al. (2002). Growth was investigated on PYG and TSB with $0.5-2 \% \mathrm{NaCl}(\mathrm{w} / \mathrm{v})$ (at intervals of $0.5 \% \mathrm{NaCl}$ ) and at $1,4,15,22,25,28,30$ and $37{ }^{\circ} \mathrm{C}$ for 14 days. Growth at pH 4.0-11 (at intervals of $0.5 \mathrm{pH}$ units) was tested in trypticase soy broth (TSB; Oxoid), with the $\mathrm{pH}$ adjusted prior to sterilization by the addition of $\mathrm{HCl}$ or $\mathrm{NaOH}$ and measured again after sterilization. Growth under anaerobic conditions was determined by incubation in an anaerobic chamber on TSA (Oxoid) supplemented with $0.5 \%(\mathrm{w} / \mathrm{v})$ glucose or $0.1 \%(\mathrm{w} / \mathrm{v})$ potassium nitrate. Growth was evaluated on TSA, R2A agar, LB agar, nutrient agar and MacConkey agar (Oxoid). Catalase activity was determined by bubble production with $3 \%(\mathrm{v} / \mathrm{v}) \mathrm{H}_{2} \mathrm{O}_{2}$ and oxidase activity was determined using $1 \%(\mathrm{w} / \mathrm{v}) \mathrm{N}, N, N^{\prime}, N^{\prime}$ tetramethyl $p$-phenylenediamine dihydrochloride (Sigma). 
Table 1. Characteristics that differentiate strain TSBY $67^{\top}$ from its closest phylogenetic neighbours in the genus Chryseobacterium

Strains: 1, TSBY $67^{\mathrm{T}} ; 2$, C. aquaticum $10-46^{\mathrm{T}} ; 3$, C. soldanellicola PSD $1-4^{\mathrm{T}}$; 4, C. soli KACC $12502^{\mathrm{T}}$. All data were taken from this study unless otherwise stated. + , Positive; $\mathrm{w}$, weakly positive; - , negative.

\begin{tabular}{|lcccc|}
\hline Characteristic & $\mathbf{1}$ & $\mathbf{2}$ & $\mathbf{3}$ & $\mathbf{4}$ \\
\hline Growth on MacConkey agar & - & - & - & + \\
Indole production & + & - & - & - \\
Urease & - & - & - & + \\
Enzymic activities & & & & \\
$\quad$ Trypsin & + & + & - & + \\
$\quad \alpha$-Glucosidase & - & - & + & + \\
$\quad$-Acetyl- $\beta$-glucosaminidase & + & - & - & + \\
Hydrolysis of: & & & & \\
$\quad$ Starch & - & + & + & + \\
$\quad$ Tween 80 & w & W & - & + \\
DNA G+C content $(\mathrm{mol} \%)^{*}$ & 33.5 & 38.5 & 28.8 & 39.9 \\
\end{tabular}

${ }^{*}$ Data for the reference strains were taken from Kim et al. (2008), Park et al. (2006) and Weon et al. (2008).

Biochemical tests were performed using the API $20 \mathrm{E}$, API $20 \mathrm{NE}$, API $50 \mathrm{CH}$ and API ZYM systems (bioMérieux) and carbon source utilization was tested using GN2 MicroPlates (Biolog), according to the manufacturers' instructions. Results were recorded after $48 \mathrm{~h}$ at $25^{\circ} \mathrm{C}$. Tests for oxidation-fermentation, degradation of DNA, casein, Tweens 20 and 80 and starch were performed using standard methods (Barrow \& Feltham, 1993). The morphological, physiological and biochemical characteristics of strain TSBY $67^{\mathrm{T}}$ are given in Table 1 and the species description.

The 16S rRNA gene sequence of strain TSBY $67^{\mathrm{T}}$ was amplified using the bacterial universal primers $8 \mathrm{f}$ and 1492r, which correspond to positions 8-27 and 1492-1511, respectively, in the 16S rRNA gene sequence of Escherichia coli. The almost-complete 16S rRNA gene sequence (1483 bp) was compiled using SeqMan software (DNASTAR) and compared with those of related taxa available in GenBank. Multiple alignments were performed using CLUSTAL_X version 1.81 (Thompson et al., 1997). Evolutionary distances were calculated using the method of Jukes \& Cantor (1969) and phylogenetic trees were constructed using the neighbour-joining (Saitou \& Nei, 1987) and maximum-parsimony (Fitch, 1971) methods. Tree topologies were evaluated by bootstrap analysis of 1000 replications using MEGA version 4.0 (Tamura et al.,
2007). The EzTaxon server (http://www.eztaxon.org/; Chun et al., 2007) was used to calculate sequence similarity. Strain TSBY $67^{\mathrm{T}}$ showed $96.8 \% 16 \mathrm{~S}$ rRNA gene sequence similarity with $C$. aquaticum $10-46^{\mathrm{T}}$ and C. soldanellicola PSD $1-4^{\mathrm{T}}$ and lower sequence similarities with the type strains of other recognized species of the genus Chryseobacterium. In the neighbour-joining phylogenetic tree (Fig. 1), strain TSBY $67^{\mathrm{T}}$ formed a separate clade within the cluster containing C. aquaticum $10-46^{\mathrm{T}}$, C. soldanellicola PSD $1-4^{\mathrm{T}}$ and C. soli KACC $12502^{\mathrm{T}}$. These results demonstrated that the isolate did not belong to any recognized species of the genus Chryseobacterium (Stackebrandt \& Goebel, 1994; Keswani \& Whitman, 2001).

The genomic DNA of strain TSBY $67^{\mathrm{T}}$ was extracted and degraded enzymically into nucleosides and the DNA G + C content was determined as described by Tamaoka \& Komagata (1984) with the following modifications. Nucleosides were separated by HPLC using a Kromasil $\mathrm{C}_{18}$ column $(5 \mu \mathrm{m}, 4.6 \times 150 \mathrm{~mm}$; Shimadzu $)$ at room temperature. The solvent was $0.6 \mathrm{M} \mathrm{NH}_{4} \mathrm{H}_{2} \mathrm{PO}_{4}(\mathrm{pH}$ 5.6) with $2.5 \%$ acetonitrile. The DNA G $+\mathrm{C}$ content of strain TSBY $67^{\mathrm{T}}$ was $33.5 \mathrm{~mol} \%$, which was within the range reported for members of the genus Chryseobacterium.

The fatty acid methyl esters of strain TSBY $67^{\mathrm{T}}$ and the three reference strains were obtained from cells grown on TSA at $25{ }^{\circ} \mathrm{C}$ for 2 days by saponification, methylation and extraction as described by Kämpfer \& Kroppenstedt (1996) and were separated using GC (6890; Agilent). Peaks were automatically integrated and fatty acid identities and percentages were determined using the Sherlock Microbial Identification system (MIDI). The major fatty acids of strain TSBY $67^{\mathrm{T}}$ were iso- $\mathrm{C}_{15: 0}(26.9 \%)$, iso- $\mathrm{C}_{17: 0}$ $3-\mathrm{OH}(16.1 \%)$, iso- $\mathrm{C}_{17: 1} \omega 9 c(15.4 \%)$, summed feature 3 (consisting of $\mathrm{C}_{16: 1} \omega 7 c$ and/or $\mathrm{C}_{16: 1} \omega 6 c ; 7.2 \%$ ) and iso$\mathrm{C}_{16: 0} \quad 3-\mathrm{OH}(7.0 \%)$. Overall, this composition was consistent with those of the closest phylogenetic neighbours grown under the same conditions (Table 2). However, strain TSBY $67^{\mathrm{T}}$ differed by having higher proportions of iso- $\mathrm{C}_{16: 0} 3-\mathrm{OH}$ and iso- $\mathrm{C}_{16: 0}$ and lower proportions of iso- $\mathrm{C}_{15: 0}$.

In light of the phylogenetic and phenotypic evidence, strain TSBY $67^{\mathrm{T}}$ represents a novel species of the genus Chryseobacterium, for which the name Chryseobacterium xinjiangense sp. nov. is proposed.

\section{Description of Chryseobacterium xinjiangense sp. nov.}

Chryseobacterium xinjiangense (xin.jiang.en'se. N.L. neut. adj. xinjiangense pertaining to Xinjiang Province, the

Fig. 1. Neighbour-joining phylogenetic tree based on 16S rRNA gene sequences showing the relationships between strain TSBY $67^{\top}$, related members of the genus Chryseobacterium and representatives of other related genera in the family Flavobacteriaceae. Bootstrap values $(>70 \%)$ based on 1000 replications are shown at branch nodes. Asterisks indicate that the corresponding nodes were also recovered in the tree generated with the maximum-parsimony method. Weeksella virosa ATCC $43766^{\top}$ was used as an outgroup. Bar, 0.01 substitutions per nucleotide position. 


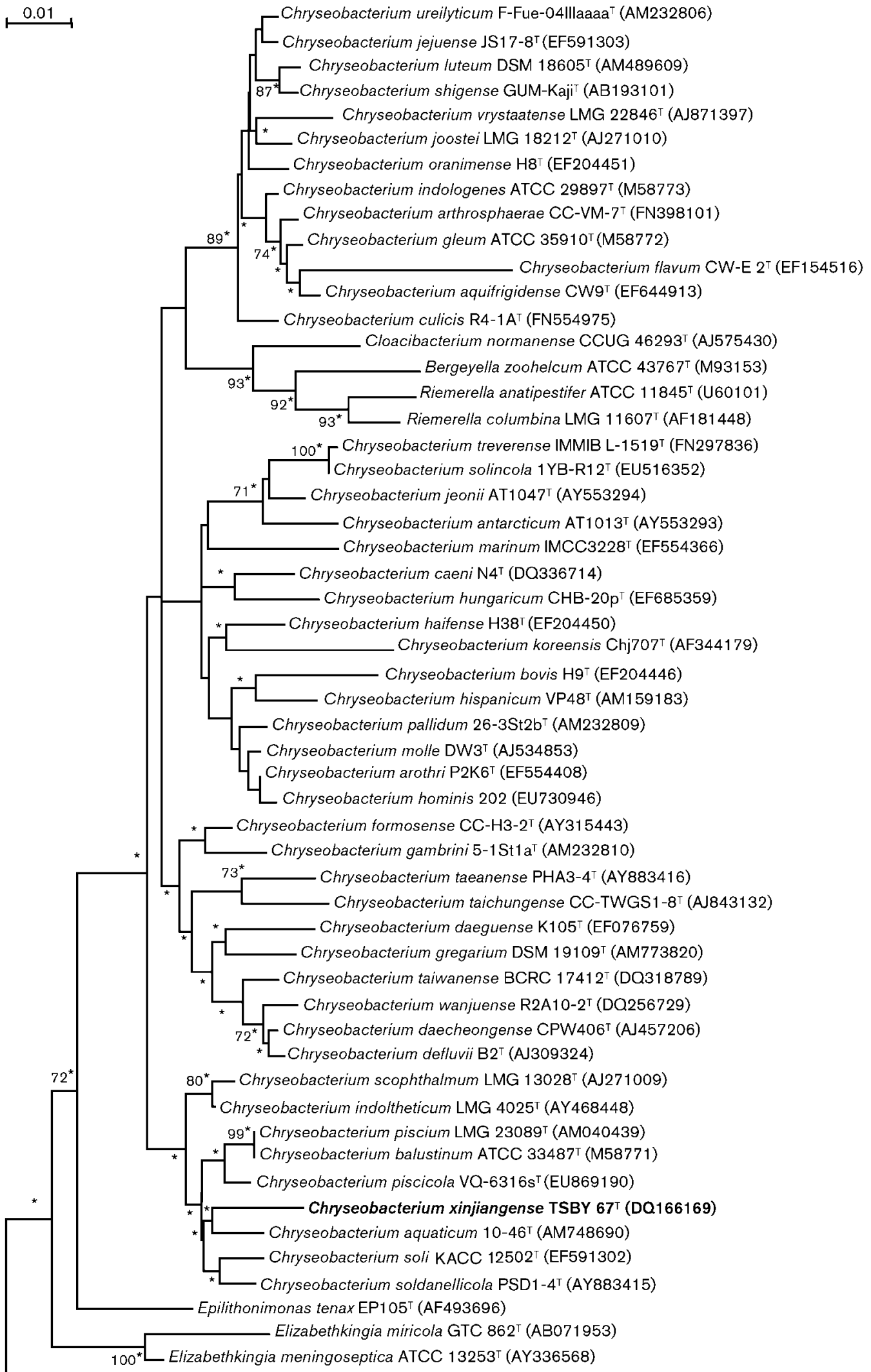

Weeksella virosa ATCC 43766' (M93152) 
source of the soil sample from which the type strain was isolated).

Cells are Gram-negative-staining, non-spore-forming, non-motile rods, $0.3-0.5 \mu \mathrm{m}$ in width and $0.6-1.6 \mu \mathrm{m}$ in length (see Supplementary Fig. S1, available in IJSEM Online). Strictly aerobic. Oxidase- and catalase-positive. Good growth occurs at $20{ }^{\circ} \mathrm{C}$ after $48 \mathrm{~h}$ on PYG, TSA, R2A agar, LB agar and nutrient agar, but not on MacConkey agar. Growth within 14 days occurs at $4-37{ }^{\circ} \mathrm{C}$ (optimum 20-24 ${ }^{\circ} \mathrm{C}$ ), at $\mathrm{pH}$ 6-8 (optimum $\mathrm{pH}$ 7) and with $0-2 \%$ $\mathrm{NaCl}$ (optimum $0.5 \% \mathrm{NaCl}$ ). Colonies are smooth and shiny, orange-yellow and circular with entire edges and become mucoid and unidentifiable as single entities after prolonged incubation. Flexirubin-type pigments are produced (positive $\mathrm{KOH}$ test). The reaction in the oxidationfermentation test is alkaline. Nitrate and nitrite are not reduced. $\mathrm{H}_{2} \mathrm{~S}$ and acetoin are not produced. Positive for production of indole and hydrolysis of gelatin, but negative for hydrolysis of aesculin, casein, starch and urea. Arginine dihydrolase, ornithine decarboxylase and lysine

Table 2. Cellular fatty acid compositions of strain TSBY $67^{\top}$ and its closest phylogenetic neighbours in the genus Chryseobacterium

Strains: 1 , TSBY $67^{\mathrm{T}} ; 2$, C. aquaticum $10-46^{\mathrm{T}} ; 3$, C. soldanellicola PSD1-4 ${ }^{\mathrm{T}} ; 4$, C. soli KACC $12502^{\mathrm{T}}$. All data were taken from this study. Values are percentages of the total. Fatty acids that amounted to $<0.5 \%$ in all strains are not shown. tr, Traces $(<0.5 \%)$; ND, not detected/not reported.

\begin{tabular}{|c|c|c|c|c|}
\hline Fatty acid & 1 & 2 & 3 & 4 \\
\hline iso- $\mathrm{C}_{13: 0}$ & $\operatorname{tr}$ & 2.3 & 1.2 & 0.7 \\
\hline iso- $\mathrm{C}_{13: 0} 3-\mathrm{OH}$ & 0.8 & $\operatorname{tr}$ & $\mathrm{ND}$ & 5.4 \\
\hline iso- $\mathrm{C}_{14: 0}$ & 0.9 & $\operatorname{tr}$ & $\operatorname{tr}$ & 0.6 \\
\hline iso- $\mathrm{C}_{15: 0}$ & 26.9 & 36.7 & 43.2 & 15.8 \\
\hline $\mathrm{C}_{15: 0} 2-\mathrm{OH}$ & 0.5 & $\operatorname{tr}$ & $\operatorname{tr}$ & ND \\
\hline iso- $\mathrm{C}_{15: 0} 3-\mathrm{OH}$ & 3.2 & 2.4 & 2.8 & 1.7 \\
\hline anteiso- $\mathrm{C}_{15: 0}$ & 2.5 & 2.6 & 1.8 & 4.0 \\
\hline iso- $\mathrm{C}_{15: 1} \mathrm{~F}$ & 0.7 & $\operatorname{tr}$ & ND & 4.6 \\
\hline anteiso- $\mathrm{C}_{15: 1} \mathrm{~A}$ & $\operatorname{tr}$ & ND & ND & 2.5 \\
\hline iso- $\mathrm{C}_{16: 0}$ & 4.3 & 0.5 & $\operatorname{tr}$ & 3.0 \\
\hline$C_{16: 0}$ & 3.0 & 9.9 & 1.2 & 9.8 \\
\hline $\mathrm{C}_{16: 0} 3-\mathrm{OH}$ & 1.7 & 5.4 & 1.4 & 1.4 \\
\hline iso- $\mathrm{C}_{16: 0} 3-\mathrm{OH}$ & 7.0 & 0.5 & $\operatorname{tr}$ & 2.1 \\
\hline $\mathrm{C}_{17: 0} 2-\mathrm{OH}$ & 1.5 & 0.8 & $\operatorname{tr}$ & 2.1 \\
\hline iso- $\mathrm{C}_{17: 0}$ & 0.6 & 1.6 & 0.5 & $\operatorname{tr}$ \\
\hline iso- $\mathrm{C}_{17: 0} 3-\mathrm{OH}$ & 16.1 & 14.8 & 15.8 & 11.3 \\
\hline iso- $\mathrm{C}_{17: 1} \omega 9 c$ & 15.4 & 6.8 & 18.0 & 8.0 \\
\hline $\mathrm{C}_{18: 1} \omega 5 c$ & 1.3 & $\operatorname{tr}$ & 0.7 & $\operatorname{tr}$ \\
\hline $\mathrm{C}_{18: 1} \omega 9 c$ & ND & ND & ND & 4.1 \\
\hline $\mathrm{C}_{18: 0}$ & 2.3 & $\mathrm{ND}$ & $\mathrm{ND}$ & 8.2 \\
\hline Summed feature $3^{*}$ & 7.2 & 11.8 & 11.2 & 7.3 \\
\hline
\end{tabular}

* Summed features represent two or three fatty acids that cannot be separated by the Microbial Identification System. Summed feature 3 consisted of $\mathrm{C}_{16: 1} \omega 6 c$ and/or $\mathrm{C}_{16: 1} \omega 7 c$. decarboxylase activities are absent. Acid is not produced from any of the 49 carbon sources in the API $50 \mathrm{CH}$ kit. With API ZYM, alkaline and acid phosphatases, esterase (C4), esterase lipase (C8), leucine arylamidase, valine arylamidase, cystine arylamidase, trypsin, naphtholAS-BI-phosphohydrolase and $N$-acetyl- $\beta$-glucosaminidase activities are present but lipase (C14), $\alpha$-chymotrypsin, $\alpha$-galactosidase, $\beta$-galactosidase, $\beta$-glucuronidase, $\alpha$-glucosidase, $\beta$-glucosidase, $\alpha$-mannosidase and $\alpha$-fucosidase activities are absent. With GN2 MicroPlates, the following compounds are utilized as sole carbon sources: dextrin, glycogen (weakly), Tweens 40 and 80, cellobiose, D-fructose, $\alpha$-D-glucose (weakly), D-mannose, acetic acid, $\alpha$-ketobutyric acid, $\alpha$-ketovaleric acid, propionic acid, L-alanyl glycine, L-asparagine, L-aspartic acid, L-glutamic acid, glycyl L-aspartic acid, glycyl L-glutamic acid, L-leucine, L-phenylalanine, L-proline, L-serine, L-threonine, inosine, uridine (weakly), thymidine, glucose 1-phosphate (weakly) and D-glucose 6-phosphate (weakly); does not utilize $\alpha$-cyclodextrin, $\mathrm{N}$-acetyl-D-galactosamine, $\mathrm{N}$-acetyl-D-glucosamine, adonitol, L-arabinose, D-arabitol, i-erythritol, L-fucose, D-galactose, gentiobiose, myo-inositol, lactose, lactulose, maltose, mannitol, melibiose, methyl $\beta$-D-glucoside, D-psicose, raffinose, L-rhamnose, D-sorbitol, sucrose, trehalose, turanose, xylitol, pyruvic acid methyl ester, succinic acid monomethyl ester, cis-aconitic acid, citric acid, formic acid, D-galactonic acid lactone, D-galacturonic acid, D-gluconic acid, D-glucosaminic acid, D-glucuronic acid, $\alpha$-, $\beta$ - and $\gamma$-hydroxybutyric acid, $p$-hydroxyphenylacetic acid, itaconic acid, $\alpha$-ketoglutaric acid, DL-lactic acid, malonic acid, quinic acid, D-saccharic acid, sebacic acid, succinic acid, bromosuccinic acid, succinamic acid, glucuronamide, alaninamide, D-alanine, L-alanine, L-histidine, hydroxy-L-proline, L-ornithine, L-pyroglutamic acid, D-serine, DL-carnitine, $\gamma$-aminobutyric acid, urocanic acid, phenylethylamine, putrescine, 2-aminoethanol, 2,3-butanediol, glycerol or DL- $\alpha$-glycerol phosphate. The most abundant cellular fatty acids $(>7 \%)$ are iso- $\mathrm{C}_{15: 0}$, iso$\mathrm{C}_{17: 0} 3-\mathrm{OH}$, iso- $\mathrm{C}_{17: 1} \omega 9 c$, summed feature $3\left(\mathrm{C}_{16: 1} \omega 6 c\right.$ and/or $\left.\mathrm{C}_{16: 1} \omega 7 c\right)$ and iso- $\mathrm{C}_{16: 0} 3-\mathrm{OH}$.

The type strain is TSBY $67^{\mathrm{T}}\left(=\right.$ NRRL B- $51308^{\mathrm{T}}=$ CCTCC $\mathrm{AB} 207183^{\mathrm{T}}$ ), isolated from alpine permafrost in Tianshan Mountains, Xinjiang Province, China. The $\mathrm{G}+\mathrm{C}$ content of the type strain is $33.5 \mathrm{~mol} \%$.

\section{Acknowledgements}

We thank Dr Jung Sook Lee, Dr Seung Bum Kim and the Korean Agricultural Culture Collection (KACC) for providing the type strains of C. aquaticum, C. soldanellicola and C. soli, respectively, and Dr Chengxiang Fang at the China Center for Type Culture Collection (CCTCC) for performing the fatty acid analysis. We also thank Dr Jean-François Bernardet for helpful comments on this manuscript. This study has been supported by the National Outstanding Youth Foundation of China (grant number 30625008), the International Cooperation Program of the Ministry of Science and Technology of China, the National High Technology Research and Development Program (grant number 2007AA021401), the National Basic Research 
Program of China (grant number 2007CB108902) and the National Natural Science Foundation (grant number 30700082).

\section{References}

Bai, Y., Yang, D., Wang, J., Xu, S., Wang, X. \& An, L. (2006). Phylogenetic diversity of culturable bacteria from alpine permafrost in the Tianshan Mountains, northwestern China. Res Microbiol 157, 741-751.

Barrow, G. I. \& Feltham, R. K. A. (editors) (1993). Cowan and Steel's Manual for the Identification of Medical Bacteria, 3rd edn. Cambridge: Cambridge University Press.

Bernardet, J. F., Nakagawa, Y. \& Holmes, B. (2002). Proposed minimal standards for describing new taxa of the family Flavobacteriaceae and emended description of the family. Int J Syst Evol Microbiol 52, 1049-1070.

Chun, J., Lee, J.-H., Jung, Y., Kim, M., Kim, S., Kim, B. K. \& Lim, Y.-W. (2007). EzTaxon: a web-based tool for the identification of prokaryotes based on 16S ribosomal RNA gene sequences. Int J Syst Evol Microbiol 57, 2259-2261.

Fitch, W. M. (1971). Toward defining the course of evolution: minimum change for a specific tree topology. Syst Zool 20, 406-416.

Gerhardt, P., Murray, R. G. E., Wood, W. A. \& Krieg, N. R. (1994). Methods for General and Molecular Bacteriology. Washington, DC: American Society for Microbiology.

Hantsis-Zacharov, E. \& Halpern, M. (2007). Chryseobacterium haifense sp. nov., a psychrotolerant bacterium isolated from raw milk. Int J Syst Evol Microbiol 57, 2344-2348.

Hantsis-Zacharov, E., Senderovich, Y. \& Halpern, M. (2008). Chryseobacterium bovis sp. nov., isolated from raw cow's milk. Int J Syst Evol Microbiol 58, 1024-1028.

llardi, P., Fernández, J. \& Avendaño-Herrera, R. (2009). Chryseobacterium piscicola sp. nov., isolated from diseased salmonid fish. Int J Syst Evol Microbiol 59, 3001-3005.

Jukes, T. H. \& Cantor, C. R. (1969). Evolution of protein molecules. In Mammalian Protein Metabolism, vol. 3, pp. 21-132. Edited by H. N. Munro. New York: Academic Press.

Kämpfer, P. \& Kroppenstedt, R. M. (1996). Numerical analysis of fatty acid patterns of coryneform bacteria and related taxa. Can J Microbiol 42, 989-1005.

Kämpfer, P., Lodders, N., Vaneechoutte, M. \& Wauters, G. (2009a). Transfer of Sejongia antarctica, Sejongia jeonii and Sejongia marina to the genus Chryseobacterium as Chryseobacterium antarcticum comb. nov., Chryseobacterium jeonii comb. nov. and Chryseobacterium marinum comb. nov. Int J Syst Evol Microbiol 59, 2238-2240.

Kämpfer, P., Vaneechoutte, M., Lodders, N., De Baere, T., Avesani, V., Janssens, M., Busse, H.-J. \& Wauters, G. (2009b). Description of Chryseobacterium anthropi sp. nov. to accommodate clinical isolates biochemically similar to Kaistella koreensis and Chryseobacterium haifense, proposal to reclassify Kaistella koreensis as Chryseobacterium koreense comb. nov. and emended description of the genus Chryseobacterium. Int J Syst Evol Microbiol 59, 2421-2428.
Keswani, J. \& Whitman, W. B. (2001). Relationship of $16 \mathrm{~S}$ rRNA sequence similarity to DNA hybridization in prokaryotes. Int J Syst Evol Microbiol 51, 667-678.

Kim, K. K., Kim, M. K., Lim, J. H., Park, H. Y. \& Lee, S.-T. (2005). Transfer of Chryseobacterium meningosepticum and Chryseobacterium miricola to Elizabethkingia gen. nov. as Elizabethkingia meningoseptica comb. nov. and Elizabethkingia miricola comb. nov. Int J Syst Evol Microbiol 55, 1287-1293.

Kim, K. K., Lee, K. C., Oh, H.-M. \& Lee, J.-S. (2008). Chryseobacterium aquaticum sp. nov., isolated from a water reservoir. Int J Syst Evol Microbiol 58, 533-537.

Li, Y., Kawamura, Y., Fujiwara, N., Naka, T., Liu, H., Huang, X., Kobayashi, K. \& Ezaki, T. (2003). Chryseobacterium miricola sp. nov., a novel species isolated from condensation water of space station Mir. Syst Appl Microbiol 26, 523-528.

Park, M. S., Jung, S. R., Lee, K. H., Lee, M. S., Do, J. O., Kim, S. B. \& Bae, K. S. (2006). Chryseobacterium soldanellicola sp. nov. and Chryseobacterium taeanense sp. nov., isolated from roots of sand-dune plants. Int J Syst Evol Microbiol 56, 433-438.

Saitou, N. \& Nei, M. (1987). The neighbor-joining method: a new method for reconstructing phylogenetic trees. Mol Biol Evol 4, 406425.

Shimomura, K., Kaji, S. \& Hiraishi, A. (2005). Chryseobacterium shigense sp. nov., a yellow-pigmented, aerobic bacterium isolated from a lactic acid beverage. Int J Syst Evol Microbiol 55, 19031906.

Stackebrandt, E. \& Goebel, B. M. (1994). Taxonomic note: a place for DNA-DNA reassociation and $16 \mathrm{~S}$ rRNA sequence analysis in the present species definition in bacteriology. Int J Syst Bacteriol 44, 846849.

Tamaoka, J. \& Komagata, K. (1984). Determination of DNA base composition by reversed-phase high-performance liquid chromatography. FEMS Microbiol Lett 25, 125-128.

Tamura, K., Dudley, J., Nei, M. \& Kumar, S. (2007). MEGA4: Molecular evolutionary genetics analysis (MEGA) software version 4.0. Mol Biol Evol 24, 1596-1599.

Thompson, J. D., Gibson, T. J., Plewniak, F., Jeanmougin, F. \& Higgins, D. G. (1997). The CLUSTAL_X windows interface: flexible strategies for multiple sequence alignment aided by quality analysis tools. Nucleic Acids Res 25, 4876-4882.

Vandamme, P., Bernardet, J.-F., Segers, P., Kersters, K. \& Holmes, B. (1994). New perspectives in the classification of the flavobacteria: description of Chryseobacterium gen. nov., Bergeyella gen. nov., and Empedobacter nom. rev. Int J Syst Bacteriol 44, 827-831.

Vaneechoutte, M., Kämpfer, P., De Baere, T., Avesani, V., Janssens, M. \& Wauters, G. (2007). Chryseobacterium hominis sp. nov., to accommodate clinical isolates biochemically similar to CDC groups II-h and II-c. Int J Syst Evol Microbiol 57, 2623-2628.

Weon, H.-Y., Kim, B.-Y., Yoo, S.-H., Kwon, S.-W., Stackebrandt, E. \& Go, S.-J. (2008). Chryseobacterium soli sp. nov. and Chryseobacterium jejuense sp. nov., isolated from soil samples from Jeju, Korea. Int J Syst Evol Microbiol 58, 470-473. 